\title{
Postnatal development of testicular cell populations in mice
}

\author{
R. P. F. A. Vergouwen ${ }^{1}$, R. Huiskamp ${ }^{2}$, R. J. Bas ${ }^{2}$, \\ H. L. Roepers-Gajadien ${ }^{1}$, J. A. G. Davids ${ }^{3}$ and D. G. de Rooij ${ }^{1}$ \\ ${ }^{1}$ University of Utrecht, Department of Cell Biology, Medical School, Section of Cell Proliferation and \\ Differentiation, Yalelaan 1, PO Box 80.157, 3508 TD Utrecht, The Netherlands; ${ }^{2}$ Department of \\ Radiobiology and Radioecology, Unit Radiation Technology, Netherlands Energy Research Foundation \\ ECN, Westerduinweg 3, PO Box 1, 1755 ZG Petten, The Netherlands; and ${ }^{3}$ Lonbar Petrilaan 28, \\ 2051 EJ Overveen, The Netherlands
}

The postnatal development of body and testis weight and the size of the testicular cell populations were studied in CBA mice up to day 52 post partum. The body weight increased from $1.3 \mathrm{~g}$ at day 1 to $22.5 \mathrm{~g}$ at day 52 . Over the same interval the testis weight showed a faster increase from about $1 \mathrm{mg}$ to almost $60 \mathrm{mg}$. Spermatogenesis was found to be complete by day 35. The numbers of A spermatogonia, Sertoli cells, Leydig cells, mesenchymal cells, macrophages, myoid cells, lymphatic endothelial cells, endothelial cells and perivascular cells per testis were studied from day 3 to day 50, using the disector method. The number of $\mathrm{A}$ spermatogonia increased from $0.2 \times 10^{5}$ at day 3 to $6.5 \times 10^{5}$ at day 21 and remained more or less constant thereafter. The Sertoli cell population increased during the first three weeks after birth to reach the adult level of approximately $18 \times 10^{5}$ cells per testis. In the interstitium the Leydig cells showed a sharp increase between days 11 and 31 followed by a small decrease to ultimately $9 \times 10^{5}$ cells per testis. The Leydig cells formed $8 \%$ of the total number of interstitial cells per testis at day 11 , increasing to $30 \%$ at day 50 . The number of mesenchymal cells did not change until day 36, decreasing thereafter from about $2.5 \times 10^{5}$ to $1 \times 10^{5}$ cells per testis at day 50 . However, the percentage of the total number of interstitial cells that were mesenchymal cells decreased from $59 \%$ to $4 \%$. The number of macrophages per testis increased very slowly from almost zero at day 3 to about $1 \times 10^{5}$ at day 28. Except for a sharp peak of $2.5 \times 10^{5}$ at day 31 , this level was maintained. The populations of myoid cells, lymphatic endothelial cells and endothelial cells showed major increases during the third, fourth and fifth week after birth to $6.5 \times 10^{5}, 3.7 \times 10^{5}$ and $4.5 \times 10^{5}$ cells per testis, respectively. The total number of perivascular cells was found to be approximately $2 \times 10^{5}$ and did not change significantly. These results show that the major cell populations in the mouse testis have reached their adult size by the end of the fifth week after birth. The changes in numbers per testis of the various cell types during development were found to be closely related to their proliferative activity.

\section{Introduction}

The proliferative activity of the types of testicular cell during development has been the subject of a number of studies. Most of the data on this subject have been obtained in rats and have often concerned germ cells and Sertoli cells (Sapsford, 1962; Steinberger and Steinberger, 1971; Orth, 1982; Kluin et al., 1984); only a few have dealt with the interstitial cell types (Baillie, 1961; Hardy et al., 1989). We described the proliferative activity of various types of cell in the developing mouse testis (Vergouwen et al., 1991). Spermatogenesis was found to start at the day of birth. The first A spermatogonia could be recognized at day 3 post partum and these cells were actively proliferating. The proliferative activity of Sertoli cells was high at birth and decreased up to day 17 post partum, whereafter they ceased proliferation. Leydig cells showed a relatively low proliferative activity during the first three weeks after birth; proliferative activity increased to a maximum at day 29 post partum and then decreased rapidly. The other types of interstitial cell featured a decreasing proliferative activity during the first two weeks after birth. Hereafter, the proliferation remained constant at a low level.

Little attention has been paid to the population sizes of the various types of testicular cell during postnatal development. Because the duration of the cell cycle of most cell types and the size of the initial cell populations is unknown, it is not possible to translate the observed cell proliferation into a growth rate of the various cell populations. Hardy et al. (1989) determined the total numbers of various types of interstitial cell per testis in the developing rat. The number of Leydig cells per testis was found 
to be low during the first three weeks after birth and to increase rapidly thereafter. However, the number of mesenchymal cells increased gradually up to day 28 post partum, like all other types of interstitial cell, but decreased clearly between days 28 and 56 post partum. These findings supported the hypothesis that there is a precursor-product relationship between mesenchymal cells and Leydig cells (Mancini et al., 1963; Hooker, 1970; Teerds et al., 1987).

The changes in population size of A spermatogonia, Sertoli cells and interstitial cell types were studied between days 3 and 50 post partum in mice, using a stereological method called the disector method (Sterio, 1984). This method proved to be very useful for a reliable determination of numbers of cells in the immature (Hardy et al., 1989) and mature testis (Mendis-Handagama et al., 1989; Keeney and Ewing, 1990).

\section{Materials and Methods}

\section{Animals}

Inbred mice of the $\mathrm{CBA} / \mathrm{P}$ substrain were used. Animals were housed under standard laboratory conditions and food and water were provided ad libitum. The day of birth was defined as day I post partum. Males were killed at daily intervals up to day 31 post partum and thereafter at intervals of 3 days up to day 52 post partum. Each age group consisted of 8-14 animals. After weighing, the animals were killed by decapitation and the testes were removed and weighed. The testes of $4-5$ mice at days 3 , $11,18,21,25,28,31,35,36,43$ and 50 post partum were prepared for histological examination.

\section{Histology and stereology}

The testes were fixed by immersion in Bouin's fluid for at least $12 \mathrm{~h}$ and embedded in Technovit 7100 (Kulzer \& Co., Wehrheim). One testis of each animal was sectioned completely with a $3 \mu \mathrm{m}$ setting on the microtome. The total number of sections obtained per testis was recorded. At least five sets of two adjacent sections were taken throughout the testis with intervals of 100 sections between two sets. The sets of sections were stained using the periodic acid-Schiff (PAS) method and used for stereological analysis.

The disector method (Sterio, 1984) was used to determine the total number of cells per testis for two tubular cell types (A spermatogonia and Sertoli cells) and seven interstitial cell types (Leydig cells, macrophages, myoid cells, lymphatic endothelial cells, endothelial cells, perivascular cells and mesenchymal cells). The A spermatogonia were recognized by their location near the basal lamina and their ovoid nucleus, showing little or no heterochromatin. Often a nucleolus was visible. Sertoli cells, macrophages and perivascular cells were identified as described by Vergouwen et al. (1991). Leydig, myoid, lymphatic endothelial, endothelial and mesenchymal cells were distinguished according to the criteria described by Hardy et al. (1989). No attempt was made to distinguish between fetal and adult type Leydig cells which were present during testicular development (Mendis-Handagama et al., 1987).

The total number of cells per testis $\left(N_{t}\right)$ for each type of cell was calculated by multiplication of the volume of the testis in the plastic embedded state $\left(V_{\mathrm{e}}\right)$ by the numerical density $\left(N_{\mathrm{v}}\right) . V_{\mathrm{e}}$ was estimated by multiplication of the total number of sections obtained from the testis by section thickness $(T)$ and the mean area of every hundredth section obtained from the testis. $N_{v}$ was calculated in the following way: $N_{\mathrm{v}}=\left(Q^{-} / A T\right)$. Here, $Q^{-}$ is the number of unique nuclear profiles in the test area $(A)$. Section thickness $(T)$ was estimated by differential focusing using a $\times 100$ oil-immersion objective and was found to be $2 \mu \mathrm{m}$ on average.

\section{Image analysis}

A black and white CCD videocamera (MO-type High Technology Holland, Eindhoven) which was mounted on a Zeiss microscope (Zeiss, Germany) was used so that the disector method for scoring unique nuclear profiles could be applied. The video signal was sent to a personal computer (Compaq $386 \mathrm{~s}$ ) extended with a frame grabber (PCVisionplus ${ }^{\circledR}$ (Imaging Technology)). The image of an area on the first of two adjacent sections was digitized by the framegrabber and displayed on a videomonitor (Sony Triniton ${ }^{\circledR}$ ). The same area located on the second serial section with the same orientation as the first area was then displayed on a second black and white videomonitor (KHi (OVM-12A) Himmelreich GmbH \& Co., Swaigern). A standard image processing software package $\operatorname{TIM}^{\circledR}$ (TEA Image Manager, DIFA, Breda) running under MS-DOS ${ }^{\circledR}$ and extended with application routines was used. A rectangular panel was projected over the image of the first section which represented an area of $3750 \mu \mathrm{m}^{2}$ on the tissue section. For each type of cell, the number of unique nuclear profiles within this panel was counted. The nuclear profiles that fell on either the left or the upper boundaries of the panel were excluded. Nuclear profiles that touched the right or lower boundaries of the panel were included in the count, even if most of the profile fell outside the panel. A total of 60 disector areas was counted for each animal; this corresponds with a total disector volume of $450000 \mu^{3}$.

\section{Statistical analysis}

Statistical analysis was performed by nonparametric analysis of variance. In the case of apparent significant differences between groups $(P<0.05)$, the Bonferroni $t$ tests were applied to define the significance of the differences.

\section{Results}

\section{Body and testis weight and tubular diameter}

The body weight of mice increased gradually from $1.3 \mathrm{~g}$ at day 1 to $17.2 \mathrm{~g}$ at day 37 , and more slowly thereafter to approximately $22.5 \mathrm{~g}$ at day 52 (Fig. Ia). The weight of the testes increased slowly from less than $1 \mathrm{mg}$ at day 1 and 2 and reached a plateau of about $60 \mathrm{mg}$ after day 37 (Fig. 1b).

\section{Histology}

The immersion fixation of Bouin's fluid proved to be adequate to preserve a good morphology, even for the largest testes. On Downloaded from Bioscientifica.com at 04/26/2023 12:40:36AM 


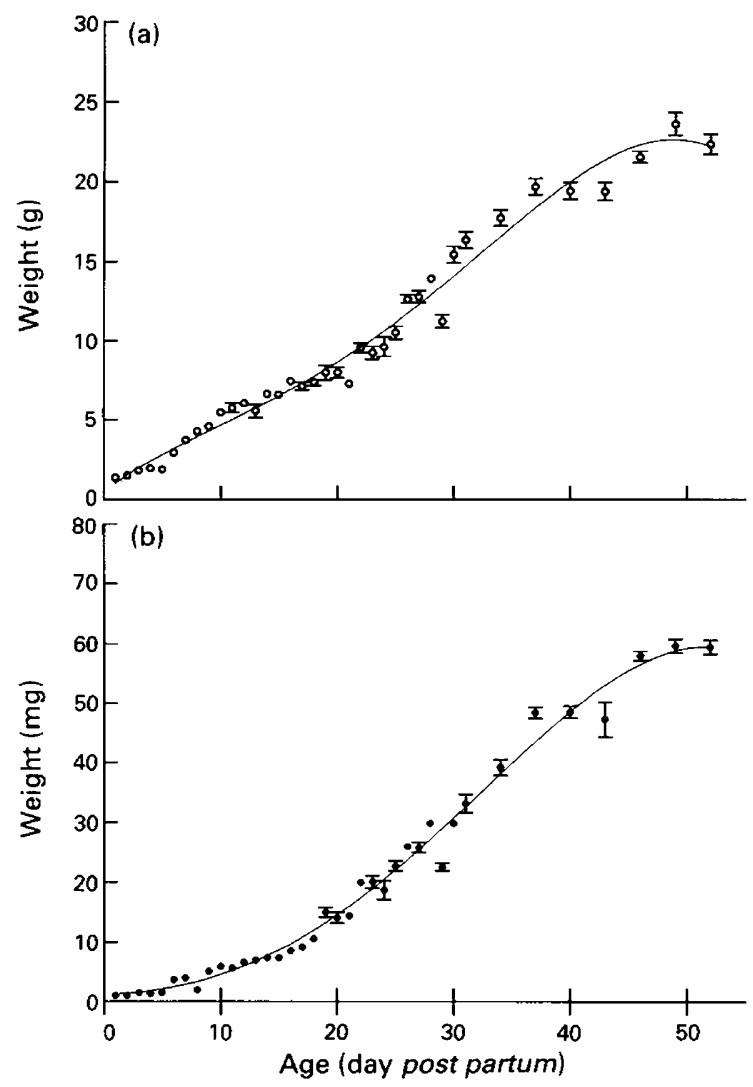

Fig. 1. Regression curves of (a) body weight and (b) testis weight of the developing mouse from birth up to day 52. Bars indicate SEM.

day 3, gonocytes, at different stages of the cell cycle, indicated by the wide variation in nuclear size, were present in the centre of the seminiferous tubules. Occasionally along the basal membrane spermatogonia could be seen (Fig. 2a). No gonocytes were observed in the testis at day 1I; the most advanced type of germ cell was the leptotene spermatocyte. At day 18 spermatogenesis had proceeded up to the pachytene spermatocyte. Some round spermatids could be seen in the testis at day 21 (Fig. 2b, c) and these cells were frequently found on day 25 . At days 28 and 31 , elongated spermatids were seen. Spermatogenesis was complete by day 35 , as all stages of the cycle of the seminiferous epithelium had a full complement of germ cell generations. No apparent morphological changes occurred in the testes of older animals (Fig. 2d-f).

On day 3 the Sertoli cells showed an immature morphology (Fig. 2a). Their nuclei were droplet shaped and showed several nucleoli. By day 18, the Sertoli cells were morphologically mature, which was indicated by the appearance of the characteristic tripartite nucleolus. The number of Sertoli cells per tubular cross-section seemed to decrease after day 18 (Fig. 2b-f).

On day 3 the interstitial spaces were relatively large and predominantly filled with mesenchymal cells. Small clusters of Leydig cells were present between these mesenchymal cells (Fig. 2a). With increasing age, the number of mesenchymal cells seemed to decrease. As the diameter of the tubules increased with age the interstitial spaces appeared to decrease. From day 18 onwards, the number of Leydig cell clusters decreased, while more and more separate Leydig cells were found (Fig. 2c). From day 25 onwards the Leydig cell was the predominant cell type in the interstitium (Fig. $2 d-f$ ).

\section{Number of cells}

The number of $\mathrm{A}$ spermatogonia per testis increased significantly from $0.2 \times 10^{5}$ at day 3 to about $6.0 \times 10^{5}$ cells per testis after day 25 (Fig. 3a). The number of Sertoli cells increased sharply and significantly from $3.5 \times 10^{5}$ at day 3 to finally about $18 \times 10^{5}$ per testis (Fig. 3a). The number of Leydig cells per testis started to increase after day 11 to approximately $9 \times 10^{5}$ with a maximum value of almost $12 \times 10^{5}$ at day 31 (Fig. 3b). The number of mesenchymal cells fluctuated between about $1 \times 10^{5}$ and $3.5 \times 10^{5}$ cells per testis (Fig. 3b). The number of macrophages per testis gradually increased from almost zero to about $1 \times 10^{5}$ after day 3 with a significant sharp peak of more than $2.5 \times 10^{5}$ at day 31 (Fig. 3c). The total number of myoid cells per testis increased significantly from about $2 \times 10^{5}$ at day 18 to about $7 \times 10^{5}$ after day 36 (Fig. 3c). The lymphatic endothelial cells could be identified only from approximately day 10 onwards (Leeson and Leeson, 1963; Vergouwen et al., 1991). The number of lymphatic endothelial cells per testis increased significantly from almost $I \times 10^{5}$ at day 18 to a more or less constant level of approximately $4 \times 10^{5}$ after day 31 (Fig. 3c). The number of endothelial cells per testis increased significantly from $0.2 \times 10^{5}$ at day 11 to over $5 \times 10^{5}$ at day 28 . Thereafter, their number fluctuated at about $4.5 \times 10^{5}$ cells per testis (Fig. 3d). No significant changes were found in the total number of perivascular cells per testis during postnatal testicular development; there were about $2.5 \times 10^{5}$ (Fig. $3 \mathrm{~d}$ ).

The total number of interstitial cells per testis showed a significant increase from almost $4 \times 10^{5}$ on day 3 to about $35 \times 10^{5}$ after day 31 (Fig. 4). The relative number of Leydig cells fluctuated markedly but a significant overall increase from about $8 \%$ at day 3 to over $30 \%$ at day 50 of the total number of interstitial cells was found. At the same time, the relative number of mesenchymal cells decreased clearly from about $59 \%$ of the total number of interstitial cells on day 3 to approximately $4 \%$ on day 50 . Except for the endothelial cells, which increased from about $5 \%$ to approximately $15 \%$, the relative numbers of the other types of interstitial cell remained similar at all ages studied. Their respective average percentages of the total number of interstitial cells were: macrophages $5 \%$; myoid cells $22.5 \%$; lymphatic endothelium $15 \%$; endothelium $15 \%$ and perivascular cells $8 \%$.

\section{Discussion}

Using the disector method, we were able to obtain a complete overview of the postnatal development of the sizes of the populations of A spermatogonia, Sertoli cells and the various types of interstitial cell. The results indicate that the types of tubular cell studied (A spermatogonia and Sertoli cells) reach their adult population size within the first three weeks after birth. Between day 1 and day 52, an increase in testis weight was observed, which proceeded much faster (60-fold) than the increase in body Downloaded from Bioscientifica.com at 04/26/2023 12:40:36AM 

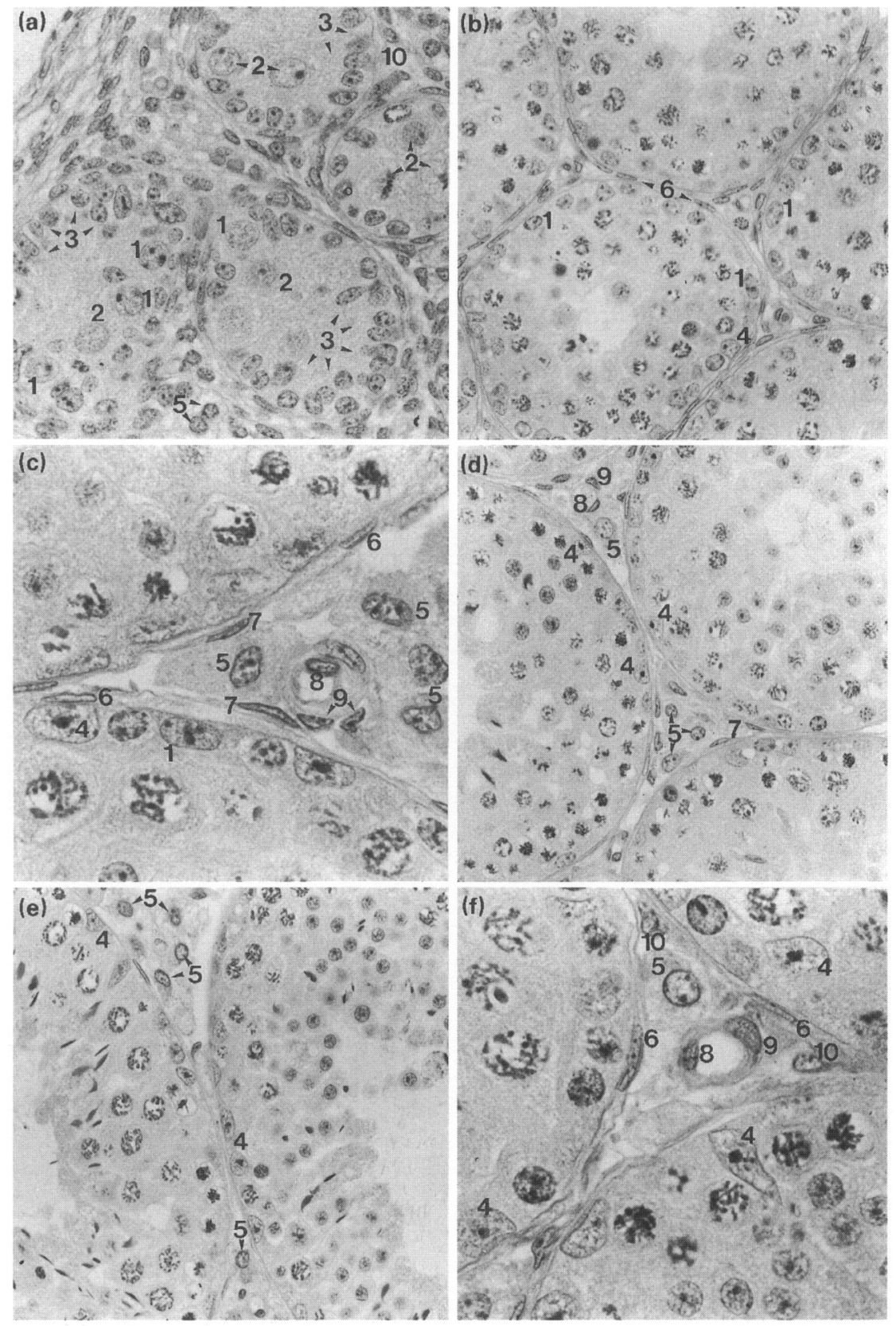

Fig. 2. Photomicrographs of testis sections at (a) day 3 post partum $(\times 370)$, (b) day 21 post partum $(\times 270)$, (c) day 21 post partum $(\times 670)$, (d) day 31 post partum $(\times 270)$, (e) day 43 post partum $(\times 270)$ and $(f)$ day $50(\times 670)$. 1: A spermatogonium; 2: gonocyte; 3: immature Sertoli cell; 4: mature Sertoli cell; 5: Leydig cell; 6: myoid cell; 7: lymphatic endothelial cell; 8: endothelial cell; 9: perivascular cell; 10: mesenchymal cell.

weight during the same period (17-fold). The slow increase in testis weight during the first two weeks after birth is probably mainly the result of the development of the first types of germinal cell. However, the rate of increase of testis weight was faster between day 15 and day 37. The major outgrowth of the interstitial cell populations started at the end of the second week after birth, which was somewhat later than that of the epithelium. Consequently, from the third up to the fifth week after birth, both the developing seminiferous epithelium and the developing interstitium contributed to the increasing testis weight. By day 35, spermatogenesis was complete. Thereafter, the gain in testis weight decreased slowly as only the developing interstitial cell population remained to increase testis weight.

The number of Sertoli cells did not change significantly after day 18. This corresponds to our earlier finding that, in CBA/P mice, the Sertoli cells cease to proliferate at approximately day 17 (Vergouwen et al., 1991). The total number of Sertoli cells per testis stabilized at $18 \times 10^{5}$ after day 18 . Kochar and Bateman (1969) estimated the number of Sertoli cells per testis 


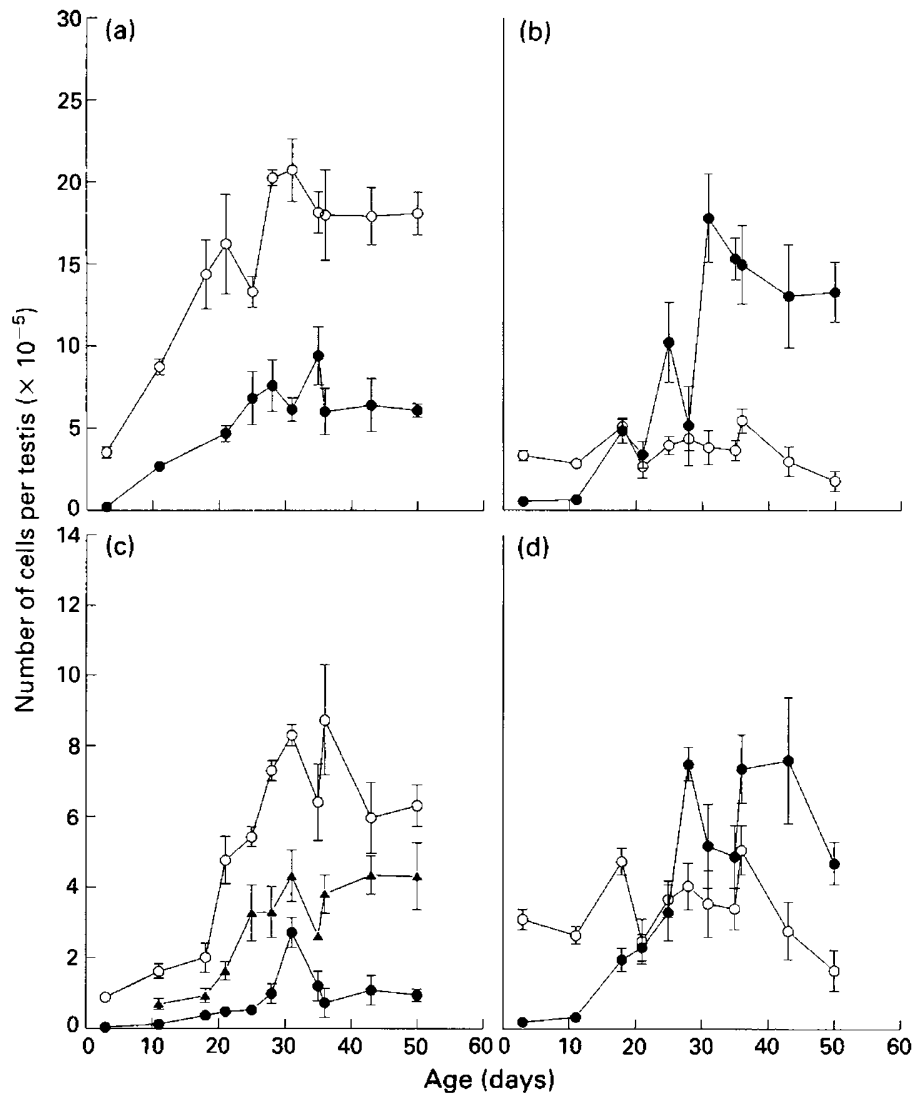

Fig. 3. Total number of cells per testis in the developing mouse from day 3 to day 50. (a) $\bigcirc$, Sertoli cells; - A spermatogonia; (b) - . Leydig cells; $\bigcirc$, mesenchymal cells; (c) $\bigcirc$, macrophages; $\bigcirc$, myoid cells; $\boldsymbol{\Delta}$, lymphatic endothelium; (d) 0 , endothelium; $\bigcirc$, perivascular cells. Bars indicate SEM.

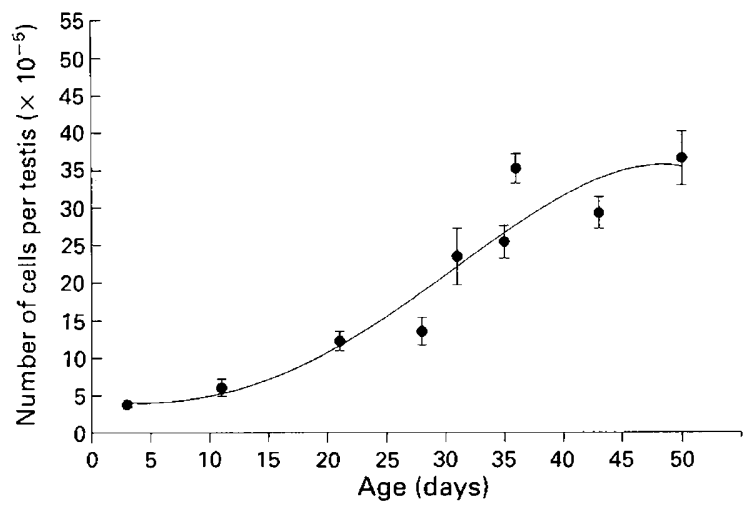

Fig. 4. Regression curves of the total number of interstitial cells per testis in the developing mouse from day 3 and day 50. Bars indicate SEM.

in adult mice of an unknown strain and reported a total of about $80 \times 10^{5}$ Sertoli cells per testis, which is 4.5 times the number we found in $\mathrm{CBA} / \mathrm{P}$ mice. It is unlikely that interstrain differences can cause this large difference in the number of Sertoli cells. However, the number of Sertoli cells counted by Kochar and Bateman (only ten tubular cross-sections) may have been too small to estimate the number of Sertoli cells reliably. Furthermore, these authors used the volume of the fixed testis instead of that of the embedded testis, to estimate the total number of Sertoli cells per testis. As paraffin embedding will induce some shrinkage of the tissue, this may have caused an increase in the density of the Sertoli cells from the fixed to the embedded state. Consequently, this may have led to higher calculated numbers of Sertoli cells per testis.

We observed a major increase in the number of Leydig cells per testis between days 21 and 31 . Thereafter, a slight decrease was observed between days 31 and 43 . This increase corresponds to previous findings of an increasing proliferative activity of the Leydig cells between day 21 and day 29 , followed by a sharp decrease thereafter (Vergouwen et al., 1991).

Several studies in a variety of species suggest that the population of mesenchymal cells forms the source of precursors for the adult type of Leydig cell (Mancini et al., 1963; Hooker, 1970; Lording and deKretser, 1972; Gondos et al., 1977; Van Straaten and Wensing, 1978; Wartenberg, 1981; Teerds et al., 1987; Hardy et al., 1989). Indeed, Hardy and co-workers provided evidence that the development of the population of adult-type Leydig cells takes place by differentiation from interstitial precursor cells and by the proliferation of existing Leydig cells.

In the present study, the number of mesenchymal cells per testis remained constant up to day 36 , although the proliferative activity is relatively high during the first two weeks after birth (Vergouwen et al., 1991). Furthermore, after day 36, the 
number of mesenchymal cells decreased significantly, while they, although very moderately, did proliferate (Vergouwen et al., 1991). These seemingly contrasting findings can be explained by the differentiation of some mesenchymal cells into Leydig cells. When expressed as a percentage of the total number of interstitial cells, the Leydig cells increased from $8 \%$ at day 21 to $30 \%$ at day 50 , while the mesenchymal cells decreased from 56 to $4 \%$. These results are similar to those reported by Hardy et al. (1989) in rats. These authors observed a 12-fold increase in the total number of Leydig cells per testis between days 21 and 56, and an increase from 7 to about $50 \%$ of the total number of interstitial cells. Apparently, although in rats a larger increase was found in the absolute and relative number of Leydig cells, the postnatal development of the Leydig cell population in mice and rats occurs in a comparable way. Our results are in accordance with the hypothesis that the precursor cells for the Leydig cells are recruited from the mesenchymal cell population.

Limited numbers of macrophages were observed in the developing mouse testis. Except for an unexplainable peak at day 31, a total number of $1 \times 10^{5}$ macrophages per testis was found. This represents about $5 \%$ of the total number of interstitial cells per testis. There are conflicting reports on the number of macrophages in immature animals. In rats, Hardy et al. (1989) found that the number of macrophages between days 21 and 28 was over $5 \%$ of the total number of interstitial cells. However, Themmen et al. (1987) could not detect any macrophages in isolated interstitial cells from rats at 21-24 days of age. However, macrophages are numerous in the testis of the adult rats (Niemi et al., 1986; Themmen et al., 1987) and mice (Hume et al., 1984), representing about $20 \%$ of the total number of interstitial cells. We conclude that, at least in mice, the major outgrowth of the population of macrophages occurs after puberty.

The populations of myoid cells, lymphatic endothelial cells, endothelial cells and perivascular cells appear to develop in a similar way in both mice and rats (Hardy et al., 1989), except for the fact that the major increase in the number per testis occurs somewhat earlier in mice than in rats (day 18 and day 21 , respectively). However, this is not surprising, as testicular development in mice is known to start a few days earlier than in rats (Sapsford, 1962). After birth, the myoid cells show a decreasing proliferative activity up to day 14 . Thereafter, they continue to proliferate at a constant but low level (Vergouwen et al., 1991). However, we observed the largest increase in the number of myoid cells per testis between day 18 and day 30. Furthermore, the lymphatic endothelial cells can be distinguished only from about day 10 onwards (Leeson and Leeson, 1963; Ross, 1967) showing a very low proliferative activity (Vergouwen et al., 1991). Again, a major increase in the number of lymphatic endothelial cells per testis occurred between day 18 and day 30 . The exact nature of these increases in the numbers of myoid cells and lymphatic endothelial cells, which is correlated with a low proliferative activity, remains unclear. It may be explained by differentiation of mesenchymal cells into these cell types in a similar way to that of the Leydig cells. Further studies are necessary to investigate this hypothesis.

The number of perivascular cells per testis remained constant during development which corresponds to their low level of proliferative activity after birth (Vergouwen et al., 1991). The number of endothelial cells significantly increased between day 11 and day 28. These cells show a more or less constant proliferative activity after birth (Vergouwen et al., 1991) at a level which is somewhat higher than that of the other interstitial cells. This level of proliferative activity is probably enough to account for the observed increase in the number of endothelial cells per testis.

The present results provide an overview of the postnatal development of the populations of A spermatogonia, Sertoli cells and the various interstitial cell types. Our data show that the maturation of the tubular cell population precedes that of the interstitial cell populations by about one week and that the development of most of the cell populations can be explained by their proliferative activity during development. Furthermore, they support the hypothesis that Leydig cell precursors are recruited from the mesenchymal cells.

The authors wish to thank R. Dol, H. J. G. van de Kant and S. G. P. M. Jacobs for their skilful technical assistance. This work was supported by the J. A. Cohen Institute for Radiopathology and Radioprotection, Leiden.

\section{References}

Baillie A (1961) Observations on the growth and histochemistry of the postnatal prepubertal mouse testis Journal of Anatomy 95 357-370

Gondos B, Morrison KP and Renston RH (1977) Leydig cell differentiation in the prepubertal rabbit testis Biology of Reproduction 17 745-748

Hardy MP, Zirkin BR and Ewing LL (1989) Kinetic studies on the development of the adult population of Leydig cells in the testis of the pubertal rat Endocrinology 124 762-770

Hooker CW (1970) The intertubular tissue of the testis. In The Testis Vol 1, pp 483-550 Ed. AD Johnson, WR Gomes and NL Van Denmark. Academic Press, New York

Hume DA, Halpin D, Charlton H and Gordon S (1984) The mononuclear phagocyte system of the mouse defined by immunocytochemical localization of antigen F4/80: macrophages of endocrine organs Proceedings of the National Academy Sciences USA 81 4174-4177

Keeney DS and Ewing LL (1990) Effects of hypophysectomy and alterations in spermatogenic function on Leydig cell volume, number, and proliferation in adult rats Journal of Andrology 11 367-378

Kluin PhM, Kramer MF and de Rooij DG (1984) Proliferation of spermatogonia and Sertoli cells in maturing mice Anatomy and Embryology 169 73-78

Kochar NK and Bateman AJ (1969) Post-irradiation changes in Sertoli cells Journal of Reproduction and Fertility 18, 265-273

Leeson CR and Leeson TS (1963) The postnatal development and differentiation of the boundary tissue of the seminiferous tubule of the rat Anatomical Record $147243-249$

Lording DW and de Kretser DM (1972) Comparative ultrastructural and histochemical studies of the interstitial cells of the rat testis during fetal and postnatal development Journal of Reproduction and Fertility 29 261-269

Mancini RE, Vilar O, Lavieri JC, Andrada JA and Heinrich JJ (1963) Development of Leydig cells in the human testis. A cytological, cytochemical and quantitative study American Journal of Anatomy 112 203-214

Mendis-Handagama SMLC, Risbridger GP and Dekretser DM (1987) Morphometric analysis of the components of the neonatal and the adult rat testis interstitium International Journal of Andrology 10 525-534

Mendis-Handagama SLMC, Keeney DS, Hardy MP and Ewing LL (1989) Application of the dissector method to enumerate cells in the testis Annals of the New York Academy of Science 564 86-98

Niemi M, Sharpe RM and Brown WR (1986) Macrophages in the interstitial tissue of the rat testis Cell and Tissue Research 243 337-344

Orth JM (1982) Proliferation of Sertoli cells in fetal and postnatal rats: a quantitative autoradiographic study Anatomical Record 37 125-137

Ross MH (1967) The fine structure and development of the peritubular contractile cell component in the seminiferous tubules of the mouse American Journal of Anatomy $121523-558$ 
Sapsford CS (1962) Changes of the cells of the sex cords and seminiferous tubules during the development of the testis of the rat and mouse Australian Journal of Zoology 10 178-194

Steinberger A and Steinberger E (1971) Replication pattern of Sertoli cells in maturing rat testis in vivo and in organ culture Biology of Reproduction 4 $84-87$

Sterio DC (1984) The unbiased estimation of number and sizes of arbitrary particles using the dissector joumal of Microscopy 134 127-136

Teerds KJ, de Rooij DG, Rommerts FFG, Stocco D, Wensing CJG, Closset J and Hennen G (1987) Regulation of the proliferation and differentiation of Leydig cells in the immature rat testis Serono Symposium Program of the 7th Workshop on Development and Function of the Reproductive Organs (Turku, Finland) p 30 (Abstract)
Themmen APN, Molenaar R, Visser WJ, Jongkind JF, Rommerts FFG and van der Molen HJ (1987) Comparison of the cellular composition and steroidogenic properties of preparations of interstitial cells isolated from immature and mature rat testis Joumal of Endocrinology 112 361-366

Van Straaten HWM and Wensing CJG (1978) Leydig cell development in the testis of the pig Biology of Reproduction $1886-93$

Vergouwen RPFA, Jacobs SGPM, Huiskamp R, Davids JAG and de Rooij DG (1991) Proliferative activity of gonocytes, Sertoli cells and interstitial cells during testicular development in mice Joumal of Reproduction and Fertility 93 233-243

Wartenberg $H$ (1981) Differentiation and development of the testes. In The Testis pp 39-80 Eds H Burger and DM deKretser. Raven Press, New York 